\title{
Efficacy of Oil Based Formulations of Nomuraea rileyi (Farlow) Samson against Spodoptera litura in vitro
}

\author{
G. Bindu Bhargavi", K. Manjula, A. Ramakrishna Rao and B. Ravindra Reddy \\ Department of Entomology, S.V. Agricultural College, ANGRAU, Tirupati-517 502, \\ A.P., India \\ *Corresponding author
}

Keywords

Nomuraea rileyi, Oil

formulations, Vegetable

oils, Mineral oils, Triton-

X 100, Larval mortality

Article Info

Accepted:

24 September 2018

Available Online:

10 October 2018

\begin{abstract}
A B S T R A C T
The liquid formulations of Nomuraea rileyi, an important entomopathogenic fungus were prepared by using two vegetable oils and two mineral oils viz., olive oil, rice bran oil, liquid paraffin oil, heavy grade mineral oil. $N$. rileyi spore mass was harvested from culture plates and mixed to autoclaved test oils in the proportions of $0.1 \mathrm{~g}\left(0.5 \times 10^{8}\right.$ spores $/ 0.1 \mathrm{~g})$ and $0.2 \mathrm{~g}\left(0.1 \times 10^{9}\right.$ spores $\left./ 0.2 \mathrm{~g}\right)$ per $100 \mathrm{ml}$. Triton-X 100 , a wetting agent was also used in two different concentrations i.e., $0.05 \%$ and $0.1 \%$ for all four test oils. The pathogenicity of $N$. rileyi conidia was studied at monthly intervals up to 5 months and mortality percentages of third instar larva of $S$. litura was calculated. Among the 16 oil based formulations of $N$. rileyi, rice bran oil with $0.2 \mathrm{~g}$ spores and $0.1 \mathrm{ml}$ triton-X 100 oil formulation recorded highest larval mortality of 78-91 per cent followed by liquid paraffin with $0.2 \mathrm{~g}$ spores and $0.1 \mathrm{ml}$ triton-X 100 and heavy grade mineral oil with $0.2 \mathrm{~g}$ spores and $0.1 \mathrm{ml}$ triton-X 100 oil formulation which recorded 74-89 and 69-86 per cent respectively. The remaining formulations recorded $28-85$ per centlarval mortality.
\end{abstract}

\section{Introduction}

An indiscriminate use of chemical pesticides is posing threat to environment and human health. Many species of insect pests have significantly developed resistance to different group of chemical insecticides.

So, works on alternate ecofriendly strategies have been initiated, that reduces the negative influence of chemical pesticides.

One line of such strategies is use of microbial agents/microbial pesticides such as bacteria, virus, fungi, nematodes, protozoa etc.
Usage of entomopathogenic fungi against insect pests gained importance from the last few decades. More than 750 species of fungi, mostly deuteromycetes and entomophthorales, are pathogenic to insects. Species that have been most intensively investigated as mycoinsecticides in the crop pest control include Beauveria bassiana, Lecanicillium lecanii, Metarhizium anisopliae, Nomuraea rileyi, Paecilomyces fumosoroseus, $P$. farinosus, Entomophthora sp., Fusarium sp. and Aspergillus sp. They are specific to insects and do not infect host plants. These fungi are cosmopolitan in their distribution and diversity. 
Due to their eco-friendly and bio-persistence behavior and easily preference to kill pest species at different developmental stages, their utilization increases day-by-day (Sultana et al., 2017). Nomuraea rileyi (Farlow) Samson is a deuteromycetous fungus of cosmopolitan nature. $N$. rileyiis an important mortality factor for many lepidopteran insects throughout the world. It has the potential to cause spectacular epizootics under favorable environmental conditions. In India, epizootics of $N$. rileyi were recorded on lepidopteran insect pests in field crops and forest trees. In Andhra Pradesh also regular occurrence of $N$. rileyi is being observed on Helicoverpa armigera, Spodoptera litura, Plusia sps etc., in crops like groundnut, cotton under favorable ecosystem.

The main objective of this study is to evaluate the oil based formulations of $N$. riley against third instar larvae of Spodoptera litura.

\section{Materials and Methods}

The standard medium used for isolation and mass production of $N$. rileyi was SDAY medium (Saboraud's Dextrose Agar enriched with Yeast extract medium).

\section{Maintenance of entomopathogenic fungus Nomuraea rileyi}

The medium was plated into petriplates under aseptic conditions @ $20 \mathrm{ml}$ per plate. The media plated petriplates were allowed to solidify in the laminar air flow chamber for about 15-20 min. The $N$. rileyi culture plates were taken and cut into discs with flame sterilized cork borer and the cut discs were inoculated on to the media plated plates with the help of cork borer and inoculation needle under aseptic conditions. The inoculated plates were sealed with paraffin tape, stored in incubator at $25^{\circ} \mathrm{C}$ and observed daily for the development of white distinct colonies at initial stage (Plate 1) and later for pale green to malachite green distinct colonies (Plate 2).

Preparation of oil based formulations of $N$. rileyi

The test oils used for the preparation of $N$. rileyi formulations are commonly and commercially available vegetable and mineral oils viz., Olive oil, rice bran oil, liquid paraffin oil, heavy grade mineral oil. The selected oils manufactured by standard companies were purchased. The oils were poured into sterilized conical flasks/blue cap bottles of $250 \mathrm{ml}$ and autoclaved at 15 psi pressure at $121^{\circ} \mathrm{C}$ for 15 min. Each oil was considered as a treatment and three replications were maintained (100ml/replication). The harvested spores of $N$. rileyi were mixed to the test oils in the proportions of $0.1 \mathrm{~g}$ and $0.2 \mathrm{~g}$ per $100 \mathrm{ml}$ of test oil. Triton-X 100, a wetting agent was also used in two different concentrations i.e., $0.05 \%$ and $0.1 \%$ for all four test oils for uniform mixing of spores under aseptic conditions.

Likewise a total of 16 treatments and an untreated control were maintained. These prepared oil formulations were stored in incubator at $22^{\circ} \mathrm{C}$.

\section{Preparation of spray suspensions from oil based formulations for laboratory studies:}

At the time of treatments for laboratory studies, from each oil formulation (i.e., olive oil, rice bran oil, liquid paraffin oil, and heavy grade mineral oil) $0.5 \mathrm{ml}$ quantity was taken with the help of micro pipette and mixed with $100 \mathrm{ml}$ of water taken in a beaker and shaken thoroughly.

\section{Culturing of Spodoptera litura in the Laboratory}

Culture of $S$. litura was maintained in the laboratory during the entire experimental 
period on natural feed i.e. castor leaves. The fresh castor leaves were collected from the field and washed thoroughly with tap water. Field collected eggs were kept in rearing troughs for hatching on a moist filter paper. Freshly hatched larvae were provided with fresh castor leaves in transparent plastic rearing containers and covered with muslin cloth. Castor leaves were changed daily till pupation and rearing troughs were cleaned daily. After pupation, pupae were kept for adult emergence in cages $(35 \times 25 \times 45 \mathrm{~cm})$. The emerged adults were provided with absorbent cotton swabs dipped in diluted honey (10\%) as adult food. The Castor leaves dipped in water present in a conical flask were placed inside the cage for egg laying. After egg laying the egg masses were collected into plastic containers every day and were reared on castor leaves under aseptic conditions to get disease free larvae. The hatched larvae were provided with fresh castor leaves every day. The third instar larvae were selected for laboratory studies.

\section{Bioassay method}

For testing the virulence, lab reared third instar larvae of $S$. litura was used. For this fresh castor leaves were collected from the field and washed with tap water and allowed to dry. The prepared $N$. rileyi spray suspensions of all the 16 treatments were applied to castor leaves separately on both sides with the help of atomizer or hair brush for infecting the larva. The treated leaves were kept on newspapers and allowed to air dry for about $20 \mathrm{~min}$. The treated castor leaves were placed in sterilized plastic troughs $(20 \mathrm{~cm}$ diameter). To these plastic troughs 10 uniform sized freshly moulted third instar S. litura larvae were placed, allowed to crawl and feed. From the next day, larvae are provided with fresh castor leaves.

Daily observations on post treatment changes in larvae and larval mortality were recorded. The virulence test was done at monthly intervals up to 150 days. An untreated control was also maintained. All the treatments were replicated thrice.

\section{Analysis of the Data}

The larval mortality due to oil based formulations of $N$. rileyi was expressed as per cent mortality before subjecting to statistical analysis by using the formula (Sharmila et al., 2015).

No. of larvae dead due to infection Per cent larval mortality = ------------- x 100

Total number of larva treated

\section{Results and Discussion}

\section{External changes / symptoms observed in $N$. rileyi treated larvae}

\section{Symptoms before death}

The infected larvae became sluggish and consumed less amount of food. Shrinked integument and pinkish discoloration was noticed on the ventral side of the body. Most of the larvae died in a characteristic way i.e. with slightly raised head and anterior portion of the body by firmly adhering the posterior portion to the substrate i.e., food material with the prolegs. At death, the larval bodies were very smooth.

\section{Changes after death}

Within few hours of death, the larval body became stiff. The cadavers were placed in glass containers with good RH. After one to two days, the dead larvae were covered by a thin coat of white mycelia mat of $N$. rileyi (Plate 3.) and covered densely in next $24 \mathrm{~h}$. Soon after two to four days, cadavers became malachite green in colour due to sporulation of mycelia (Plate 4.). 
The results indicate that rice bran oil with $0.2 \mathrm{~g}$ spores and $0.1 \mathrm{ml}$ triton-X 100 formulation recorded highest larval mortality at monthly intervals. At 60 and 150 DAP rice bran oil with $0.2 \mathrm{~g}$ spores and $0.1 \mathrm{ml}$ triton-X 100 oil formulation recorded 86.33 and 78.00 per cent larval mortality and showed lesser reduction of 12.67 per cent larval mortality from the day of preparation to 150 days after preparation (Table 1 and Fig. 1).

Rice bran oil is extracted from the hard outer brown layer of rice grains after chaffing. It has mild flavor and has high smoke point of $232^{\circ} \mathrm{C}$ (stabile at high temperatures). Rice bran oil consists of higher food energy of $880 \mathrm{k} \mathrm{Cal}$ per 100 gms. It is rich in antioxidants. This oil contains $38 \%$ monosaturated, $37 \%$ polyunsaturated $\mathrm{d}$ and $25 \%$ saturated fatty acids. The above properties of rice bran oil may be suitable for $N$. rileyi conidia for being more viable and virulent.

Daud et al., (2015) reported that rice bran oil is rich in natural antioxidants such as tocopherols, tocotrienols, oryzanol and phenolic compound. The total phenol content ranges from $190-450 \mathrm{mg} / \mathrm{kg}$.

Gopalakrishnan and Mohan (2000) reported that rice was the most suitable substrate for quicker and better mass multiplication of $N$. rileyi. Krishnaveni (2014) reported that maize and rice grains stands in first and second places with 96 and 80 per cent of germination of conidia of $N$. rileyi. According to Preez et al., (1985) rice contains higher proportion of starch and amylase. Hydrolysis of starch in rice resulted in the release of glucose and maltose depending on clarification.

The next best treatments are liquid paraffin with $0.2 \mathrm{~g}$ spores and $0.1 \mathrm{ml}$ triton-X 100 and heavy grade mineral oil with $0.2 \mathrm{~g}$ spores and $0.1 \mathrm{ml}$ triton-X 100 oil formulations which recorded 82.00 and 79.33 per cent larval mortality at 60 DAP and 74.33 and 69.00 per cent larval mortality at 150 DAP. They showed relatively lesser reduction of 14.34 and 16.67 per cent respectively.

Mineral oils are liquid by-products of refining crude oil to make gasoline and other petroleum products. They are transparent, colorless oil composed mainly of alkanes from a mineral source and cycloalkanes, related to petroleum jelly.

When cost of oils also concerned, rice bran oil is found to be cheaper followed by liquid paraffin. The olive oil with $0.1 \mathrm{~g}$ spores and $0.05 \mathrm{ml}$ of triton-X 100 formulation recorded 44.00 and 28.00 per cent larval mortality at 60 and 150 DAP and has shown relatively highest reduction of 22.00 per cent of virulence of conidia of $N$. rileyi.

Olive oil is a liquid fat, produced by pressing whole olives. It mainly consists of oleic acid, with smaller amount of other fatty acids like linoleic acid and palmitic acid. It has favorable flavor. It has a smoke point of $190-210^{\circ} \mathrm{C}$. This oil contains $13.33 \mathrm{~g}$ of saturated and $66.6 \mathrm{~g}$ of monosaturated fatty acids, with $800 \mathrm{k}$ $\mathrm{Cal}$ energy per $100 \mathrm{~g}$. When compared to rice bran oil, olive oil has relatively lower smoke point and less saturated fatty acids. These properties of olive oil may be comparatively less favorable for the conidia of $N$. rileyi to maintain viability and virulence.

Muco et al., (2015) reported that olive oil contains palmitic, palmitoleic, stearic, oleic, linoleic, linolenic, and arachidic fatty acids. The total phenol content ranged from 117-304 $\mathrm{mg} / \mathrm{kg}$. These physico-chemical properties of olive oil might be highly unfavorable for $N$. rileyi spores for retaining the viability and pathogenicity. The remaining treatments, rice bran oil with $0.2 \mathrm{~g}$ spores and $0.05 \mathrm{ml}$ of triton$\mathrm{X} 100$, liquid paraffin with $0.2 \mathrm{~g}$ spores and $0.05 \mathrm{ml}$ of triton-X 100, heavy grade mineral 
oil with $0.2 \mathrm{~g}$ spores and $0.05 \mathrm{ml}$ of triton $-\mathrm{X}$ 100 , rice bran oil with $0.1 \mathrm{~g}$ spores and $0.1 \mathrm{ml}$ of triton-X 100 , olive oil with $0.2 \mathrm{~g}$ spores and $0.1 \mathrm{ml}$ of triton-X 100 , rice bran oil with $0.1 \mathrm{~g}$ spores and $0.05 \mathrm{ml}$ triton-X 100 , heavy grade mineral oil with $0.1 \mathrm{~g}$ spores and $0.1 \mathrm{ml}$ of triton-X 100 , liquid paraffin with $0.1 \mathrm{~g}$ spores and $0.1 \mathrm{ml}$ of triton-X 100, heavy grade mineral oil with $0.1 \mathrm{~g}$ spores and $0.05 \mathrm{ml}$ of triton-X 100 , liquid paraffin with $0.1 \mathrm{~g}$ spores and $0.05 \mathrm{ml}$ of triton-X 100, olive oil with $0.2 \mathrm{~g}$ spores and $0.05 \mathrm{ml}$ of triton-X 100 and olive oil with $0.1 \mathrm{~g}$ spores and $0.1 \mathrm{ml}$ of tritonX 100 oil formulations has shown 18-21 per cent reduction in virulence of conidia of $N$. rileyi from the day of preparation to 150 days of preparation.

When two spore loads i.e. $0.1 \mathrm{~g}$ and $0.2 \mathrm{~g}$ per $100 \mathrm{ml}$ oils were compared, the higher per cent viable spores were recorded in the latter, whereas the two concentrations of wetting agent, triton-X 100 i.e. $0.05 \%$ and $0.1 \%$, the higher concentration of wetting agent found better suited for $N$. rileyi spores to retain the viability. In none of the formulation the viability was declined less than 30 per cent.
Plate.1 Vegetative growth of $N$. rileyi on SDAY medium (white mycelium)



Plate.2 Sporulated $N$. rileyi on SDAY medium (malachite green)

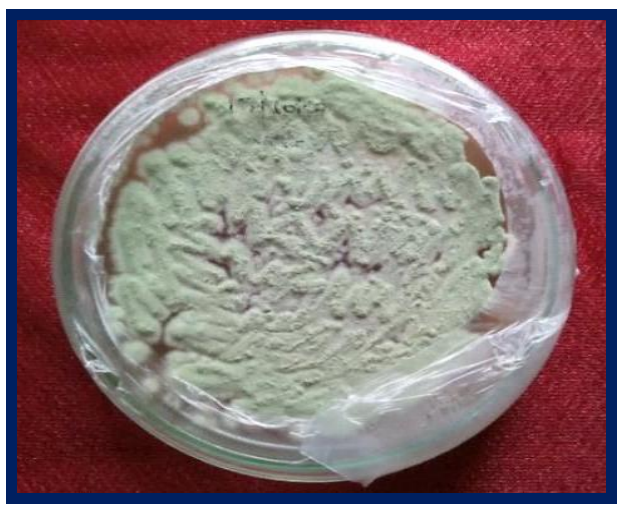

Plate.4 Sporulation of N. rileyi on cadavers (White cover is the mycelium)

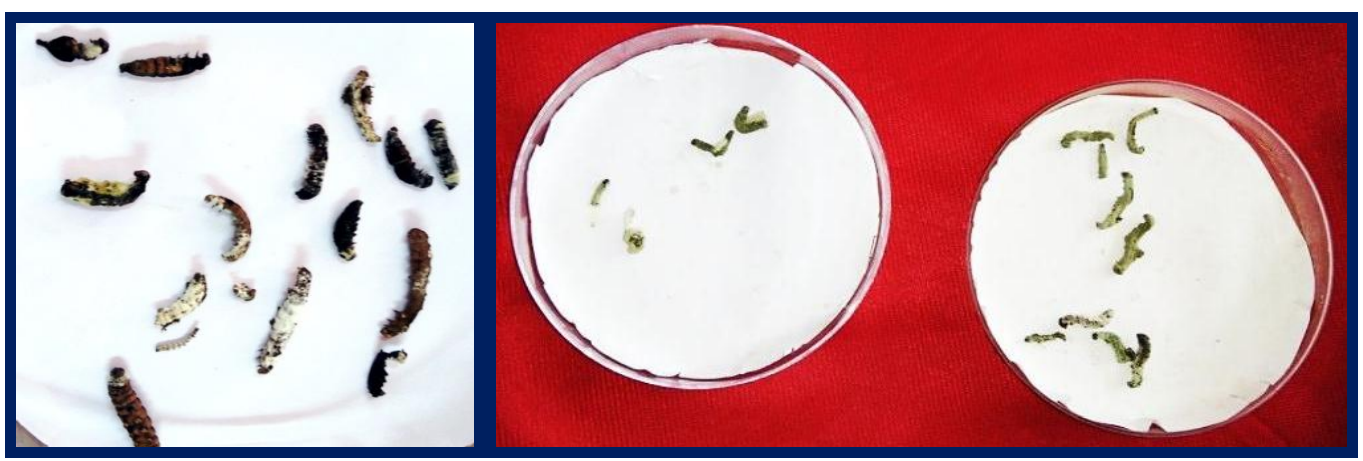


Table.1 Spodoptera litura larval mortalities recorded when third instar treated with different oil based formulations of $N$. rileyi

\begin{tabular}{|c|c|c|c|c|c|c|}
\hline \multirow{2}{*}{ Treatments } & \multicolumn{6}{|c|}{ Mean per cent larval mortality } \\
\hline & 1 DAP & 30 DAP & 60 DAP & 90 DAP & 120 DAP & 150 DAP \\
\hline $\mathbf{T}_{3}$ & $\begin{array}{c}80.00^{\mathrm{k}} \\
(63.40)\end{array}$ & $\begin{array}{c}79.00^{j} \\
(62.72)\end{array}$ & $\begin{array}{c}75.33^{\mathrm{k}} \\
(60.19)\end{array}$ & $\begin{array}{c}71.00^{k} \\
(57.39)\end{array}$ & $\begin{array}{c}67.33^{1} \\
(55.12)\end{array}$ & $\begin{array}{c}62.00^{1} \\
(51.92)\end{array}$ \\
\hline $\mathbf{T}_{5}$ & $\begin{array}{c}50.00^{b} \\
(44.98)\end{array}$ & $\begin{array}{c}46.33^{\mathrm{b}} \\
(42.89)\end{array}$ & $\begin{array}{c}44.00^{b} \\
(41.53)\end{array}$ & $\begin{array}{c}40.33^{b} \\
(39.41)\end{array}$ & $\begin{array}{c}34.00^{\mathrm{b}} \\
(35.65)\end{array}$ & $\begin{array}{c}28.00^{b} \\
(31.94) \backslash\end{array}$ \\
\hline $\mathrm{T}_{6}$ & $\begin{array}{c}51.33^{b} \\
(45.75)\end{array}$ & $\begin{array}{c}52.00^{c} \\
(46.13)\end{array}$ & $\begin{array}{l}46.00^{c} \\
(42.69)\end{array}$ & $\begin{array}{l}41.33^{c} \\
(39.99)\end{array}$ & $\begin{array}{c}37.00^{c} \\
(37.45)\end{array}$ & $\begin{array}{l}30.00^{c} \\
(33.19)\end{array}$ \\
\hline$\overline{T_{7}}$ & $\begin{array}{l}57.00^{c} \\
(49.00)\end{array}$ & $\begin{array}{c}53.33^{c} \\
(46.89)\end{array}$ & $\begin{array}{l}50.33^{\mathrm{d}} \\
(45.17)\end{array}$ & $\begin{array}{l}47.00^{\mathrm{d}} \\
(43.26)\end{array}$ & $\begin{array}{l}40.33^{\mathrm{d}} \\
(39.41)\end{array}$ & $\begin{array}{l}35.33^{\mathrm{d}} \\
(36.45)\end{array}$ \\
\hline $\mathbf{T}_{10}$ & $\begin{array}{l}77.00^{\mathrm{ij}} \\
(61.32)\end{array}$ & $\begin{array}{c}75.33^{\mathrm{h}} \\
(60.19)\end{array}$ & $\begin{array}{c}70.00^{j} \\
(56.76)\end{array}$ & $\begin{array}{c}69.33^{j} \\
(56.36)\end{array}$ & $\begin{array}{c}65.00^{j} \\
(53.71)\end{array}$ & $\begin{array}{c}58.00^{j} \\
(49.58)\end{array}$ \\
\hline$\overline{T_{11}}$ & $\begin{array}{c}85.00^{1} \\
(61.19)\end{array}$ & $\begin{array}{l}80.33^{\mathrm{jk}} \\
(63.65)\end{array}$ & $\begin{array}{c}77.67^{1} \\
(61.77)\end{array}$ & $\begin{array}{c}73.33^{1} \\
(58.89)\end{array}$ & $\begin{array}{l}69.00^{\mathrm{m}} \\
(56.14)\end{array}$ & $\begin{array}{l}67.33^{\mathrm{m}} \\
(55.12)\end{array}$ \\
\hline$\overline{T_{12}}$ & $\begin{array}{c}90.67^{n} \\
(72.34)\end{array}$ & $\begin{array}{l}90.00^{\mathrm{m}} \\
(71.55)\end{array}$ & $\begin{array}{l}86.33^{\circ} \\
(68.28)\end{array}$ & $\begin{array}{c}83.33^{\circ} \\
(65.88)\end{array}$ & $\begin{array}{l}78.33^{\mathrm{P}} \\
(62.24)\end{array}$ & $\begin{array}{c}78.00^{\mathrm{P}} \\
(62.00)\end{array}$ \\
\hline$\overline{T_{13}}$ & $\begin{array}{c}59.34^{d} \\
(50.39)\end{array}$ & $\begin{array}{c}57.33^{\mathrm{d}} \\
(49.19)\end{array}$ & $\begin{array}{l}53.33^{c} \\
(46.89)\end{array}$ & $\begin{array}{l}49.33^{\mathrm{e}} \\
(44.60)\end{array}$ & $\begin{array}{c}41.33^{\mathrm{e}} \\
(39.99)\end{array}$ & $\begin{array}{c}38.33^{\mathrm{e}} \\
(38.24)\end{array}$ \\
\hline $\mathbf{T}_{14}$ & $\begin{array}{c}70.00^{g} \\
(56.76)\end{array}$ & $\begin{array}{c}65.33^{\mathrm{e}} \\
(53.90)\end{array}$ & $\begin{array}{c}63.00^{\mathrm{h}} \\
(52.50)\end{array}$ & $\begin{array}{c}59.00^{\mathrm{h}} \\
(50.16)\end{array}$ & $\begin{array}{l}54.00^{\mathrm{h}} \\
(47.27)\end{array}$ & $\begin{array}{l}50.00^{\mathrm{h}} \\
(44.98)\end{array}$ \\
\hline$\overline{T_{15}}$ & $\begin{array}{l}78.33^{j \mathrm{k}} \\
(62.23)\end{array}$ & $\begin{array}{c}77.33^{\mathrm{i}} \\
(61.55)\end{array}$ & $\begin{array}{c}75.00^{\mathrm{k}} \\
(59.98)\end{array}$ & $\begin{array}{c}70.33^{\mathrm{k}} \\
(56.98)\end{array}$ & $\begin{array}{l}66.33^{k} \\
(54.51)\end{array}$ & $\begin{array}{c}60.00^{k} \\
(50.75)\end{array}$ \\
\hline C.D. $(p=0.05)$ & 1.78 & 1.42 & 0.87 & 1.12 & 1.01 & 1.02 \\
\hline
\end{tabular}

Figures in parenthesis indicate angular transformed values.

DAP = Days after Preparation

Means in the column followed by same letter(s) are not significantly different by DMRT

Data are the means of three replications

$\mathrm{T}_{1}$ : Liquid paraffin with $0.1 \mathrm{~g}$ spores and $0.05 \mathrm{ml}$ of Triton-X100, $\mathrm{T}_{2}$ : Liquid paraffin with $0.1 \mathrm{~g}$ spores and $0.1 \mathrm{ml}$ of Triton-X100, $\mathrm{T}_{3}$ : Liquid paraffin with $0.2 \mathrm{~g}$ spores and $0.05 \mathrm{ml}$ of Triton-X100, $\mathrm{T}_{4}$ : Liquid paraffin with $0.2 \mathrm{~g}$ spores and $0.1 \mathrm{ml}$ of Triton-X100, $\mathrm{T}_{5}$ : Olive oil with $0.1 \mathrm{~g}$ spores and $0.05 \mathrm{ml}$ of Triton-X100, $\mathrm{T}_{6}$ : Olive oil with $0.1 \mathrm{~g}$ spores and $0.1 \mathrm{ml}$ of Triton-X100, $\mathrm{T}_{7}$ : Olive oil with $0.2 \mathrm{~g}$ spores and $0.05 \mathrm{ml}$ of Triton-X100, $\mathrm{T}_{8}$ : Olive oil with $0.2 \mathrm{~g}$ spores and $0.1 \mathrm{ml}$ of Triton-X100, $\mathrm{T}_{9}$ : Rice bran oil with $0.1 \mathrm{~g}$ spores and $0.05 \mathrm{ml}$ of Triton-X100, $\mathrm{T}_{10}$ : Rice bran oil with $0.1 \mathrm{~g}$ spores and $0.1 \mathrm{ml}$ of Triton-X100, $\mathrm{T}_{11}$ : Rice bran oil with $0.2 \mathrm{~g}$ spores and $0.05 \mathrm{ml}$ of Triton-X100, $\mathrm{T}_{12}$ : Rice bran oil with $0.2 \mathrm{~g}$ spores and $0.1 \mathrm{ml}$ of Triton-X100, $\mathrm{T}_{13}$ : Heavy grade mineral oil with $0.1 \mathrm{~g}$ spores and $0.05 \mathrm{ml}$ of Triton$\mathrm{X} 100, \mathrm{~T}_{14}$ : Heavy grade mineral oil with $0.1 \mathrm{~g}$ spores and $0.1 \mathrm{ml}$ of Triton-X100, $\mathrm{T}_{15}$ : Heavy grade mineral oil with $0.2 \mathrm{~g}$ spores and $0.05 \mathrm{ml}$ of Triton-X100, $\mathrm{T}_{16}$ : Heavy grade mineral oil with $0.2 \mathrm{~g}$ spores and $0.1 \mathrm{ml}$ of Triton-X100, $\mathrm{T}_{17}$ : Untreated check. 
Fig.1 Efficacy of oil based formulations of $N$. rileyi treated to third instar $S$. litura larvae under laboratory conditions

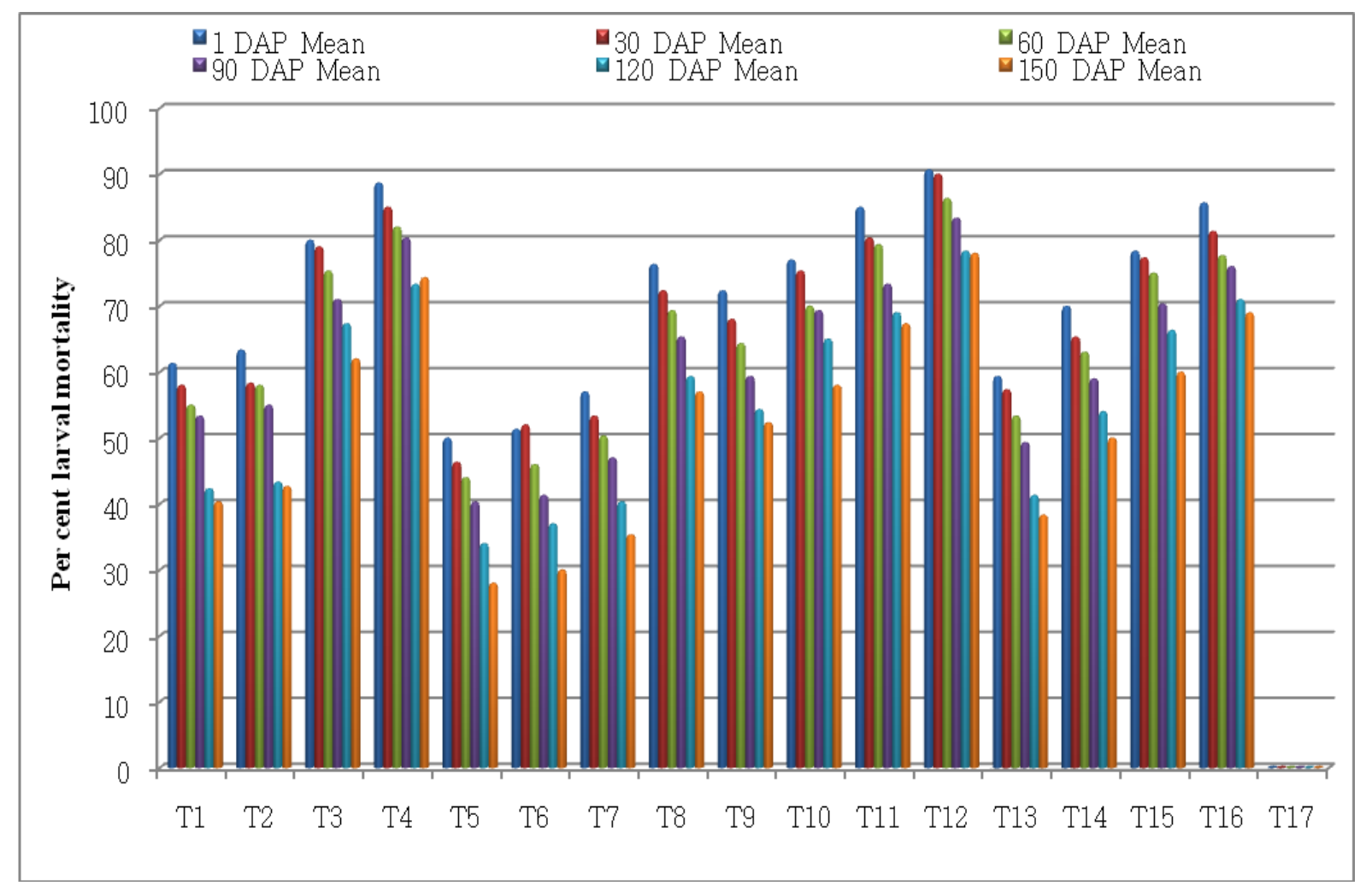

$\mathrm{T}_{1}$ : Liquid paraffin with $0.1 \mathrm{~g}$ spores and $0.05 \mathrm{ml}$ of Triton-X100, $\mathrm{T}_{2}$ : Liquid paraffin with $0.1 \mathrm{~g}$ spores and $0.1 \mathrm{ml}$ of Triton-X100, $\mathrm{T}_{3}$ : Liquid paraffin with $0.2 \mathrm{~g}$ spores and $0.05 \mathrm{ml}$ of Triton-X100, $\mathrm{T}_{4}$ : Liquid paraffin with $0.2 \mathrm{~g}$ spores and $0.1 \mathrm{ml}$ of Triton-X100, $\mathrm{T}_{5}$ : Olive oil with $0.1 \mathrm{~g}$ spores and $0.05 \mathrm{ml}$ of Triton-X100, $\mathrm{T}_{6}$ : Olive oil with $0.1 \mathrm{~g}$ spores and $0.1 \mathrm{ml}$ of Triton-X100, $\mathrm{T}_{7}$ : Olive oil with $0.2 \mathrm{~g}$ spores and $0.05 \mathrm{ml}$ of Triton-X100, $\mathrm{T}_{8}$ : Olive oil with $0.2 \mathrm{~g}$ spores and $0.1 \mathrm{ml}$ of Triton-X100, $\mathrm{T}_{9}$ : Rice bran oil with $0.1 \mathrm{~g}$ spores and $0.05 \mathrm{ml}$ of Triton-X100, $\mathrm{T}_{10}$ : Rice bran oil with $0.1 \mathrm{~g}$ spores and $0.1 \mathrm{ml}$ of Triton-X100, $\mathrm{T}_{11}$ : Rice bran oil with $0.2 \mathrm{~g}$ spores and $0.05 \mathrm{ml}$ of Triton-X100, $\mathrm{T}_{12}$ : Rice bran oil with $0.2 \mathrm{~g}$ spores and $0.1 \mathrm{ml}$ of Triton-X100, $\mathrm{T}_{13}$ : Heavy grade mineral oil with $0.1 \mathrm{~g}$ spores and $0.05 \mathrm{ml}$ of Triton$\mathrm{X} 100, \mathrm{~T}_{14}$ : Heavy grade mineral oil with $0.1 \mathrm{~g}$ spores and $0.1 \mathrm{ml}$ of Triton-X100, $\mathrm{T}_{15}$ : Heavy grade mineral oil with $0.2 \mathrm{~g}$ spores and $0.05 \mathrm{ml}$ of Triton-X100, $\mathrm{T}_{16}$ : Heavy grade mineral oil with $0.2 \mathrm{~g}$ spores and $0.1 \mathrm{ml}$ of Triton-X100, $\mathrm{T}_{17}$ : Untreated check.

Triton-X 100 is a non-ionic detergent used in various protein methods. It is accurate with precise $10 \%$ detergent solution in ultrapure water. It is easy to use and simple to dilute and dispense. It is exceptionally pure with less than $1.0 \mu \mathrm{eq} / \mathrm{ml}$ peroxides and carbonyls. It is stable, packed under inert nitrogen gas in glass.

The similar results were reported by Vimaladevi et al., (2002) who reported that the entomopathogenic fungus $N$. rileyi in sunflower oil formulation along with Triton-
X 100 showed 83.9 per cent mortality of 7 to 8 days old $S$. litura larvae, whereas, the same in sunflower oil + Tween-80 (0.02\%) has recorded only 65.7 per cent mortality under laboratory conditions

Sharma and Sharma (2017) studied intrinsic toxicity of $N$. rileyi against different larval instars of $S$. litura (Fabricius) by larval and leaf-dip method. $N$. rileyi when applied at concentrations between $10^{2}$ and $10^{9}$ conidia/ml resulted in $20-83.34,26.67-$ $100,20-80,20-96.67$ and $16.67-83.34$ per 
cent mortality of first, second, third, fourth and fifth instar larvae respectively. $\mathrm{LC}_{50}$ values $5.7 \times 10^{3}, 4.4 \times 10^{4}, 1.2 \times 10^{3}$, $1.3 \times 10^{5}$ and $8.3 \times 10^{4}$ and $\mathrm{LC}_{90}$ values $1.1 \times$ $10^{7}, 4.6 \times 10^{7}, 7.7 \times 10^{7}, 2.7 \times 10^{8}$ and $1.5 \times$ $10^{8}$ conidia/ml were for different instars. Fungus at $10^{7}$ conidia/ml took $6.9,6.2,7.1$, 6.9 and 7.6 days to kill 50 per cent and 10.2, $8.9,10.2,9.5$ and 12.6 days to kill 90 per cent of first, second, third, fourth and fifth instar larvae respectively.

Padanad (2009) evaluated the Pathogenicity of ten $N$. rileyi isolates against $S$. lituraby exposing third instars to topical application of a spore concentration of $10^{8}$ conidia/ml. All ten isolates of $N$ rileyi were active against third instars of $S$. litura, resulting in 85 to 97\% mortality. $\mathrm{LT}_{50}$ values of $N$. rileyi isolates against third instars of $S$. litura ranged from 5.5 to 6.6 days.

Vegetable oils at 0.5 per cent concentrations $(v / v)$ were emulsified in 0.02 per cent Tween 80 solution containing $2 \times 10^{10}$ conidia / 100 $\mathrm{ml}$ of spray solution. These preparations were applied after one hour to $S$. litura larvae on castor leaves and allowed to feed for $48 \mathrm{hr}$. Cumulative larval mortality nine days after treatment due to fungus indicated the similarity between treatments with vegetable oils (Safflower, groundnut, sunflower, rapeseed, mustard, sesame, cotton seed and coconut oil) indicating the safety of these vegetable oils to the fungus (Vimaladevi and Prasad, 1996).

Lezama et al., (1993) reported cent per cent mortality in I, II, III and IV instar larvae of Spodoptera frugiperda and 97.5 and 77.5 in V and VI instar larvae when treated with spore suspension of $N$. rileyi at $2.8 \times 10^{7}$ spores per $\mathrm{ml}$.

Habib and Patel (1990) carried out a laboratory experiment to study the pathogenicity of $N$. rileyi to larvae of $S$. frugiperda, at $27 \pm 2^{\circ} \mathrm{C}$ temperature and 70 percent RH. They reported that third instar larvae were more susceptible than fourth instar larvae.

Lopez and Boucias (1994) evaluated the effect of $N$. rileyi against Spodoptera exigua and recorded 50 per cent mortality at five days, 100 per cent morality at three to four with $5 \times 10^{2}, 5 \times 10^{3}$ spores $\mathrm{ml}^{-1}$.

Vimaladevi et al., (2003) conducted laboratory bioassays at a concentration of $2 \times$ $10^{8}$ conidia $\mathrm{ml}^{-1}$ of $N$. rileyi and recorded 7785 per cent mortalities in $S$. litura and $H$. armigera.

Nagaraja (2005) reported that the oil formulation of N. rileyi@ $2 \times 10^{8}$ spores per $\mathrm{ml}$ exerted considerable pathogenicity (26.2 per cent mortality) to the third instar larvae of $H$. armigeraat 3 DAT. The cumulative mortality steadily increased to reach 93.20 per cent on the $10^{\text {th }}$ day after treatment. The laboratory evaluation of $N$. rileyi formulations $v i z$, oil formulation (sunflower oil + Tween$80(0.02 \%)$, wettable powder (talc) and crude formulation at $2 \times 10^{8}$ conidia per $\mathrm{ml}$ concentration against third instar larvae of $S$. litura also was carried out. At the end of $10^{\text {th }}$ day, the highest cumulative mortality of 95 per cent was obtained in oil formulations whereas 83.10 and 77 per cent mortalities were recorded with WP and crude $N$. rileyi respectively.

Sharmila et al., (2015) evaluated oil formulations of $N$. rileyi against $S$. litura under laboratory conditions and reported more than $70 \%$ larval mortalities of S. litura in case of groundnut and sunflower oil based formulations with concentrations above $1 \mathrm{x}$ $10^{6}$ spores per $\mathrm{ml}$ and mortality reduced with concentrations showing least with $1 \mathrm{x} 10^{2}$ spores per $\mathrm{ml}$. 
Prior et al., (1988) who reported that laboratory studies primarily with grasshopper have shown that oil formulation of aerial conidia of $M$. anisopliae are more efficacious than aqueous formulation under various temperature and moisture conditions.

Prithiva et al., (2017) reported that among the different formulations tested viz., crude, talc and oil formulations, B. bassiana (Bb 112) oil formulation was most effective against whitefly on tomato with $45.86 \%$ reduction in population over control followed by talc $(29.62 \%)$ and crude formulations $(21.63 \%)$.

Shweta and Sobita (2017) reported that, per cent mortality was quiet high in earlier instars as compared to later instars. The highest dose of $5 \% 2.3 \times 10^{6}$ conidia $/ \mathrm{ml}$ brought 91.66 , $90.00,88.33,78.77,66.11$ and 49.99 percent mortality in $1^{\text {st }}, 2^{\text {nd }}, 3^{\text {rd }}, 4^{\text {th }}, 5^{\text {th }}$ and $6^{\text {th }}$ instar respectively as compared to only 11.66 , 07.21, 01.10, 00.00, 01.11 and 00.00 per cent mortality in control of respective stages. They also reported that higher the dose of $B$. bassiana higher will be the mortality of tobacco caterpillar.

\section{References}

Daud, N. S. M., Dayang, N. A. Z., Lai, K. S., Muhamad, I. I and Jusoh, Y. M. M. 2015.Antioxidant properties of Rice bran oil from different varieties extracted by solvent extraction methods. https://www.researchgate.net/publicatio $n / 277508266$.

Gopalkrishnan, C and Mohan, K. S. 2000.A simple and cost effective in vitro method for the mass production of conidia of Nomuraea rileyi (Farlow) Samson. Pest Management in Horticulture Ecosystems. 6 (1): 36-39.

Habib, M. E and Patel, P. N. 1990. Pathogenicity of Nomurea rileyi (Farlow) Samson to larvae of
Spodoptera frugiperda (Smith) a pest of corn. Revista de Agriculture. 65(1): 8390.

Krishnaveni, S. 2014. Preparation and evaluation of certain dry formulations of Nomuraea rileyi (farlow) samson, an entomopathogenic fungus. M.Sc. (Ag.) Thesis. Acharya N.G. Ranga Agricultural University.

Lezama, G. R., Alatorre, R. R., Hernan, Dez, J. L. and Gonazalez, H. 1993. In vitro sensitivity of fall armyworm larvae Spodoptera frugiperdato the fungi Paecilomyxes fumosoroseus and Nomuraea rileyi. Advances in Investigation Agropecuaria. 2: 90-99.

Lopez, L. C. C and Boucias, D. G. 1994. Studies on the cellular reactions of Spodoptera exigua larvae infected with the fungus Nomuraea rileyi. Journal of Invertebrate Pathology. 63(1): 101-102.

Muco, M., Kopali, A and Muco, L. X. 2015. Physical and chemical characteristics of olive oils from autochthonous Albanian olive varieties. Journal of Hygienic Engineering and Design.12: 66-65.

Nagaraja, S. D. 2005. Effect of formulations of Nomuraea rileyi (Farlow) Samson and spray equipments in the management of tobacco caterpillar in groundnut and pod borer in chickpea ecosystem. M.Sc. (Agri.) Thesis. University of Agricultural Sciences, Dharwad.

Padanad, M. S and Krishnaraj, P. U. 2009. Pathogenicity of native entomopathogenic fungus Nomuraea rileyi against Spodoptera litura. Plant Health Progress.

Preez, J. C., Jong, F. P., Botes, J and Lategon, T. M. 1985. Fermentation alcohol from grain sorghum starch. Biomass. 8: 101117.

Prior, C., Carey, M., Moore, D and Bateman, R. P. 1988. The enhanced infectivity of Metarhizum flavoviridae in oil 
formulations to desert locusts at low humidities. Annals Applied Biology. 122:145-152.

Prithiva, J. N., Ganapathy, N and Jeyarani, S. 2017. Efficacy of different formulations of Beauveria bassiana (Bb 112) against Bemisia tabaci on tomato. Journal of Entomology and Zoology Studies. 5(4): 1239-1243

Sharma, A and Sharma, P. L. 2017. Laboratory evaluation of a local isolate of Nomuraea rileyi (Farlow) Samson against Spodoptera litura (Fabricius) (Lepidoptera: Noctuidae). Agricultural International. 4(1): 47-50.

Sharmila, T., Manjula, K and Murali Krishna, T. 2015.Evaluation of oil formulations of Nomuraea rileyi (Farlow) Samson against Spodoptera litura under laboratory conditions. International Journal of Plant Science. 10(1): 29-32.

Shweta, A and Sobita, S. 2017.Efficacy of Beuveriabassiana on different larval instars of tobacco caterpillar (Spodoptera litura Fab.). International
Journal of Current Microbiology and Applied Sciences. 6(8): 1992-1996.

Sultana, R., Kumar, S and Yanar, D. 2017. Application of entomopathogenic fungi for insect pests control. Journal of Entomology and Zoology Studies. 5(6): 07-13.

Vimaladevi, P. S., Prasad, Y. G., Anitha Chowdary, D., Mallikarjuna Rao, L and Balakrishnan, K. 2003. Identification of virulent isolates of the entomopathogenic fungus Nomuraea rileyi (F) Samson for the management of Helicoverpa armigera and Spodoptera litura. Mycopathologia. 156: $365-373$.

Vimaladevi, P. S., Prasad, Y.G and Chowdary, A. 2002. Effect of drying and formulation of conidia on virulence of the entomofungal pathogen Nomuraea rileyi (Farlow) Samson. Journal of Biological Control. 16(1): 43-48.

\section{How to cite this article:}

Bindu Bhargavi, G., K. Manjula, A. Ramakrishna Rao and Ravindra Reddy, B. 2018. Efficacy of Oil Based Formulations of Nomuraea rileyi (Farlow) Samson against Spodoptera litura in vitro. Int.J.Curr.Microbiol.App.Sci. 7(10): 3413-3422.

doi: https://doi.org/10.20546/ijcmas.2018.710.396 